\author{
Mirosław SOŁTYSIAK ${ }^{1}$ \\ Dariusz WYRWA ${ }^{2}$
}

\title{
DILEMMAS OF THE CREATION OF INNOVATION POLICY IN MEMBER STATES
}

\begin{abstract}
Directions of changes occurring in the world economy in recent years show the transformation of the industrial economy into a knowledge-based economy, using the technological and innovative potential. This transformation has highlighted the competitive advantages of countries and regions specializing in the production of hightech products. A lot of research has been trying to find out what the drivers of innovation really are, though there has not formed one consensus. The aim of the paper is to investigate influence of research and development (R\&D) expenditure on economic growth in EU member states and to assess whether there is a significant relationship between countries' $R \& D$ efforts and their innovation and between innovation and per capita income, as postulated by R\&D based endogenous growth models. Basic source of data is Eurostat database and European Innovation Scoreboard reports. Results confirm positive and statistically significant impact of government R\&D expenditure, which is the main driver for economic growth during the analysed period. Highly developed countries are conducting research to seek new sources of innovativeness and methods for creating innovative potential. The results also suggest that the EU countries that do not have effective R\&D sectors seem to promote their innovation through technology spillovers from other countries.
\end{abstract}

Keywords: innovation, innovation policy, economic growth.

\section{INTRODUCTION}

Implementation of the innovation policy at national level requires the settlement of many dilemmas. They are connected with, among other things, what instruments and on what scale should be used. State interventionism may interfere with the functioning of free market, and consequently lead to deterioration in the condition of the bodies, which did not use the aid. The biggest controversies result primarily from grants financed from public funds, also coming from the budget of the European Union. However, most experts believe

\footnotetext{
${ }^{1}$ Mirosław Sołtysiak, PhD, Rzeszow University of technology, The Faculty of Management; Powstanców Warszawy Ave. 10, 35-959 Rzeszow, e-mail: miroslaw@ prz.edu.pl. Dr Mirosław Sołtysiak, Politechnika Rzeszowska, Wydział Zarządzania, Al. Powstańców Warszawy 10, 35-959 Rzeszów, e-mail: miroslaw@prz.edu.pl.

2 Dariusz Wyrwa, PhD, Rzeszow University of technolog,, The Faculty of Management, Powstanców Warszawy Ave. 10, 35-959 Rzeszow, e-mail: dwyrwa@prz.edu.pl (autor korespondencyjny). Dr Dariusz Wyrwa, Politechnika Rzeszowska, Wydział Zarządzania, Al. Powstańców Warszawy 10, 35-959 Rzeszów, e-mail: dwyrwa@ @rz.edu.pl (corresponding author).
} 
that in the area of innovative actions, which entail high risk, such aid is indispensable. Creating the right innovation policy requires continuous evaluation of the innovativeness of economy and the evaluation of executed programmes and used instruments, so that it is possible to modify this policy as needed.

The available data indicates that the innovation policy of many Member states, especially the so-called new Member states, does not allow to reduce the distance to the leaders. There are many factors that determine the innovativeness of economy, and the impact of some of them is not well understood through research and described. That is why sustainable development of knowledge on the mechanisms of the formation of innovation and ways to stimulate innovativeness is a prerequisite for the proper planning of public interventions. Changes in the area of public management and the emergence of an approach known as New Public Management make the public sector more and more opened for the use of management methods and techniques employed in the private sector. This model is focused on results and is to ensure cost efficiency, efficiency and effectiveness of public organisations ${ }^{3}$. Therefore, we must verify whether the employed instruments, especially of a financial nature, have been properly used to stimulate the innovativeness of economy.

The aim of the paper is to evaluate the importance of investing in R\&D for the level of innovativeness of the Member states and to identify regularities that occur in this respect. In addition, the authors attempted to indicate the necessary directions for the development of innovativeness policy, which could allow the catching-up Member states to get a better pace of innovativeness development. For the purposes of the paper, available data of the European Statistical Office was used along with the information from the European Innovation Scoreboard report.

\section{THE CONCEPT AND THE ESSENCE OF THE INNOVATIVENESS}

Innovativeness is an economic category, which can be viewed and defined on three different levels, namely at the level of enterprise, region and state (economy).

Colloquial understanding of innovativeness means something new and different from existing solutions, is associated with the need of change for the better and is very often used as a synonym for the word "change"4.

Innovativeness is usually treated as a feature of economic entities or economies, i.e. their ability to create and absorb innovation and is associated with the active engagement in innovative processes and taking appropriate actions. It can also be identified with involvement in gaining resources and skills necessary to participate in these processes ${ }^{5}$. Innovativeness of the economy is ability and willingness of economic entities to continually search for and use in practice the results of research and of research and development works, new concepts, ideas and inventions, improvement and development of the used technology of production of tangible and intangible (services) goods, implementation of new methods and techniques in the organisation and management, improvement and development of the

\footnotetext{
${ }^{3}$ A. Zalewski, Reformy sektora publicznego $w$ duchu nowego zarzadzania publicznego [in:] Nowe zarzadzanie publiczne $w$ polskim samorzadzie terytorialnym, ed. A. Zalewski, Warszawa 2007, p. 29.

4 W. Janasz, K. Kozioł, Determinanty działalności innowacyjnej przedsiębiorstw, Warszawa 2007, p. 11.

5 K.B. Matusiak (ed.), Innowacje i transfer technologii. Stownik pojęć, Warszawa 2011, p. 74.
} 
infrastructure and knowledge ${ }^{6}$, as well as the improvement of the methods of processing, collecting and sharing information ${ }^{7}$.

The above definitions of innovativeness seem clear and legible, but the problem is to measure and evaluate its level. It is beyond doubt that the higher innovativeness means greater willingness and ability of the economies and enterprises to develop innovation. However, it should be noted that definitions of innovativeness are pretty general and only cover two areas. On the one hand, they refer to broadly understood potential for creation of innovation and continuous commitment to its development (i.e. they refer to the so-called potential innovation). On the other hand, based on the approach proposed by J. Schumpeter, they indicate that we deal with innovations only when they are implemented in practice. Therefore, innovativeness must also apply to the context of the specific effects of the conducted innovative activity (it is the so-called resultative or resulting innovativeness) ${ }^{8}$. The distinction between these dimensions of innovativeness is very important, because a high innovative potential does not necessarily mean numerous implementations in the economy and translate into very good results of innovative activities carried out by enterprises. On the other hand, implementation of innovative solutions in enterprises using imported technology does not have to be a result of a high potential innovation of the economy. This can be a significant problem when attempting to assess innovativeness, especially that according to the Oslo Manual, enterprises can implement innovation with different levels of newness. It highlights innovations which are new to companies, new to the market and new to the world (i.e. breaking innovations) ${ }^{9}$. Transfer of technology in a given country can lead to numerous implementations of the same solution by different entities, which can raise e.g. the percentage of innovative enterprises, and thus affect the assessment of the level of innovativeness of the whole economy. Therefore, we are constantly looking for methodological solutions, which would allow the most objective evaluation of innovativeness. Described methodological difficulties do not affect the conviction that innovativeness is the best way to ensure the competitiveness of the economy and ensure its growth opportunities, which is confirmed by numerous studies carried out in this field.

\section{INNOVATIVENESS AS A DETERMINANT OF ECONOMIC GROWTH IN SCIENTIFIC RESEARCH}

The precursor of theory of innovation in economics is J.A. Schumpeter. According to him, innovativeness can be identified with an action which is characterised by intellectual creativity. It is important, however, that when defining innovation, Schumpeter distinguished it from the invention, noting that innovation is possible without invention, since the invention does not necessarily induce innovation, as it is not necessarily always introduced on the market ${ }^{10}$.

${ }^{6}$ P. Frankowski, B. Skubiak, Innowacyjność $w$ teorii ekonomii i praktyce gospodarczej, Studia i Prace Wydziału Nauk Ekonomicznych i Zarządzania 2012, nr 30, p. 274.

7 J. Kowalik, Analiza poziomu innowacyjności państw Unii Europejskiej, Zeszyty Naukowe Politechniki Częstochowskiej Zarządzanie 2015, nr 19, p. 22.

8 T. Nawrocki, Innowacyjność produktowa przedsiębiorstw, Warszawa 2012, p. 22-23.

9 OECD, Oslo Manual. Guidelines for Collecting and Interpreting Innovation Data, 3rd Edition, The Organisation for Economic Co-operation and Development. 2005, p. 20.

10 J.A. Schumpeter, Business Cycles: A Theoretical, Historical and Statistical Analysis of the Capitalist Process, Philadelphia 1982, p. 85. 
Innovation in the context of management was also dealt with by, among others, P.F. Drucker, who focused on the sources of innovation ${ }^{11}$ and M.E. Porter, who believed that innovation may be the most important determinant of competitive advantage of economies $^{12}$. In Polish literature, much attention to innovation was devoted by A. Pomykalski, who indicated the relationships existing between the economic and innovative processes in the entire economy and enterprise ${ }^{13}$ or $\mathrm{M}$. Weresa, who focused on the functioning of innovation systems and the implementation of innovation policy ${ }^{14}$.

Studies of technological innovations were popularised by C. Freeman in the seventies of the twentieth century. He saw the growing role of R\&D activities. He stressed that innovation is a prerequisite for economic development and a key element in the competitive struggle between enterprises and states, but also improves the quality of life of citizens and secure the potential of modern societies ${ }^{15}$.

Research conducted by G. Cameron confirms that the expenditures on research, development and innovation positively affect the economic development ${ }^{16}$, acceleration of which is most often the result of growth in productivity dynamics ${ }^{17}$. This is particularly important for the economies operating under heavy resource constraints.

The research conducted points to differences in the level of economic development of individual states, depending on the severity of their technological and innovative potential. One of the first research was carried out by J. Fagarberg, who used data from 25 states to verify the hypothesis that the level of technological development of the country has a significant impact on its economic growth. He proved that countries with low GDP per capita can, using only import or imitation in the field of technology, obtain external benefits from faster technological development of other (richer) states. This can lead to surprising dependence, which Fagarberg described as the "catching-up effect" 18 .

States, depending on their level of innovativeness, can be divided into several major categories, which differ in terms of potential of development directions. First of them is the most developed economies with high level of innovativeness. In their case, transfer of solutions from other countries is not possible, so they must incur expenditures on R\&D. In the absence of the possibility to pattern on others, they develop their own solutions. Second of them is states that are rapidly growing, mainly due to imitation and import of technology, which with low labour costs enable rapid GDP growth. However, at some level of GDP (several thousand dollars per capita), the import of advanced solutions becomes uneconomical and it is necessary to focus on the development of own innovations. Otherwise, such a state can fall into the so-called middle income trap ${ }^{19}$. Third category is states with such

${ }^{11}$ P.F. Drucker, Innowacja i przedsiębiorczość. Praktyka i zasady, Warszawa 1992, p. 44.

12 M.E. Porter, The Competitive Advantage of Nations, London 1990, p. 73.

13 A. Pomykalski, Zarzadzanie innowacjami, Warszawa-Lódź 2001.

14 M. Weresa, Polityka innowacyjna, Warszawa 2014.

${ }^{15}$ C. Freeman, L. Soete, The Economics of Industrial Innovation. 3rd Edition, London 1997.

16 G. Cameron, Innovation and Economic Growth, CEP Discussion Papers No. 277, Centre for Economic Performance, London School of Economics and Political Science, London 1996, p. 10.

${ }_{17}$ M. Khan, K.B. Luintel, Sources of Knowledge and Productivity: How Robust is the Relationship?, OECD Science, Technology and Industry Working Papers 2006, nr 6, OECD, Paris 2006.

18 J. Fagerberg, Technology Gap Approach to Why Growth Paths Differ, „Research Policy“ 1987, Vol. 16, p. 87-89.

${ }^{19}$ M. Bukowski, A. Szprot, A. Śniegocki, Innowacyjność polskiej gospodarki, „Ekonomia i Zarządzanie" 2014, nr 1, p. 6. 
a low income so that it is not possible for them to import advanced solutions. Then they have no prospects for development.

The study of $\mathrm{H}$. Ulku confirmed a strong positive relationship between innovativeness and GDP per capita in OECD countries and outside the OECD. It also turned out that the highly developed OECD countries are able to increase their innovativeness by investing in research and development, while other countries, who do not have a developed R\&D, focus on innovations resulting from the transfer of technology from other countries ${ }^{20}$.

Also, the study aimed to identify the relationships between economic growth and innovativeness in the states of Central and Eastern Europe confirmed the existence of a positive correlation between economic growth and innovations. Additional factors that may affect the growth were direct foreign investments (through the transfer of knowledge and improvement of technological processes) and education and human capital, which also confirms the truthfulness of the concept of endogenous growth ${ }^{21}$.

\section{INVESTMENTS IN THE R\&D SECTOR AS AN INSTRUMENT OF INNOVATION POLICY}

As previously mentioned, the thesis that the development of economy based on innovativeness can contribute to its growth has been confirmed in numerous studies. However, there is a problem that needs to be solved by the government of each state - it is to prepare and implement innovation policy adequate to its specifics.

Innovation policy includes different kinds of government programmes, tools, instruments, mechanisms and measures, whose aim is for the state to directly or indirectly influence the level of innovation of individual entities and sectors, and to influence the development of innovative economic structure. The main objective of the innovation policy is to ensure the efficiency of national and regional innovation systems ${ }^{22}$.

Simple ways to assess the disbursement of funds do not provide sufficient information on the effectiveness and efficiency of expenditure within innovation policy. The correlation of the amount of expenditures incurred by the Member states on R\&D (Total intramural $R \& D$ expenditure GERD) expressed in millions of euros and the number of applications in the period 2007-2014 is characterised by a high Pearson correlation coefficient, which is $0.95^{23}$. However, as previously mentioned, it is difficult to evaluate innovativeness only by the number of patent applications. The European Commission, for the needs of evaluation of the innovation policy of the states and regions of the European Union uses the European Innovation Scoreboard. A new methodology was introduced in 2017, which is designed to enable more accurate assessment of innovativeness. This year's report also contains calculations, allowing the determination of the synthetic innovativeness indicators (Summary Innovation Index) for individual States for the years 2010-2016. Their analysis indicates

${ }^{20}$ H. Ulku, R\&D, Innovation, and Economic Growth: An Empirical Analysis, „IMF Working Paper“ 2004, No. 185, p. 27.

21 A.M. Pece, O.E. Simonab, F. Salisteanuc, Innovation and economic growth: An empirical analysis for CEE countries. „Procedia Economics and Finance” 2015, No. 26, p. 466-467.

22 E. Okoń-Horodyńska, Co z narodowym systemem innowacji w Polsce? [in:] Rola polskiej nauki we wzroście innowacyjności gospodarki, ed. E. Okoń-Horodyńska, Warszawa 2004.

${ }^{23}$ D. Wyrwa, Evaluation of the efficiency of the European Union's innovative policy, „Actual Problems of Economics“" 2017, No. 1, p. 22. 
that during this period the most innovative EU countries were Sweden, Denmark, Finland, Luxembourg and Germany. In turn, the least innovative ones included Romania, Bulgaria, Poland, Latvia and Croatia.

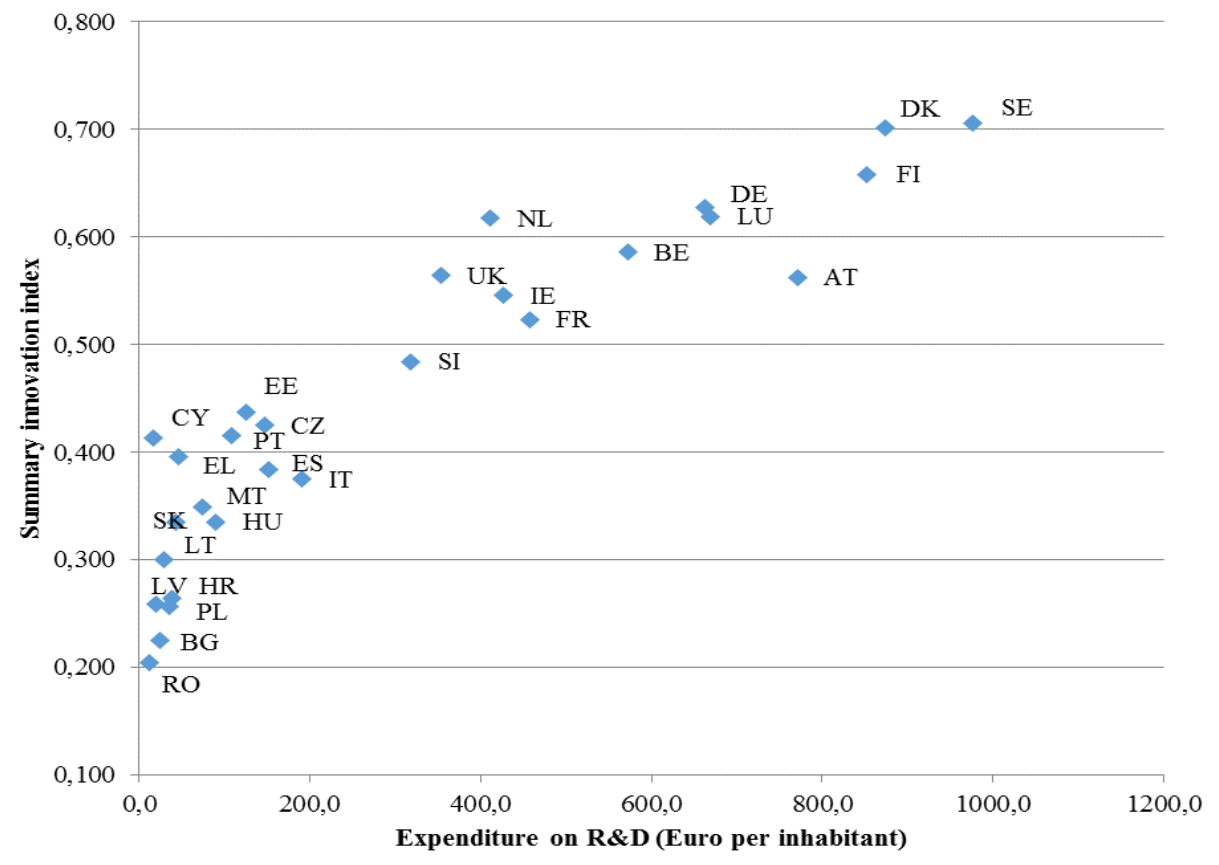

Figure 1. Relationship between expenditure on $R \& D$ and the innovativeness index (SII)

Source: own elaboration based on Eurostat data and European Innovation Scoreboard 2017.

Summary Innovation Index for the individual Member states are compiled with the data on expenditure incurred by them on R\&D activities. Figure 1 shows the relationship existing between expenditure and the innovativeness index (SII).

However, widespread belief that EU funding can make a significant contribution in stimulating innovativeness in the economy and increase its dynamics is not confirmed. One of the biggest beneficiaries of this aid, which is Poland, does not show significant progress in improving the innovative position compared to the EU average, and the designated trend line is unfavourable compared to the EU average. This is illustrated by Figure 2.

Compilation of the innovative position of state with total expenditure incurred on R\&D clearly indicates that in the case of the leaders of the ranking, expenditures are the highest. What is important, also in terms of percentage of GDP, these states invest in R\&D significantly more than the EU average. State occupying the lowest position, also in the case of expenditure on R\&D are placed low. Of course, this should not be surprising if one takes into account the methodology of assessment of innovativeness used to the needs of the European Innovation Scoreboard report, as many indicators refer to R\&D costs. 


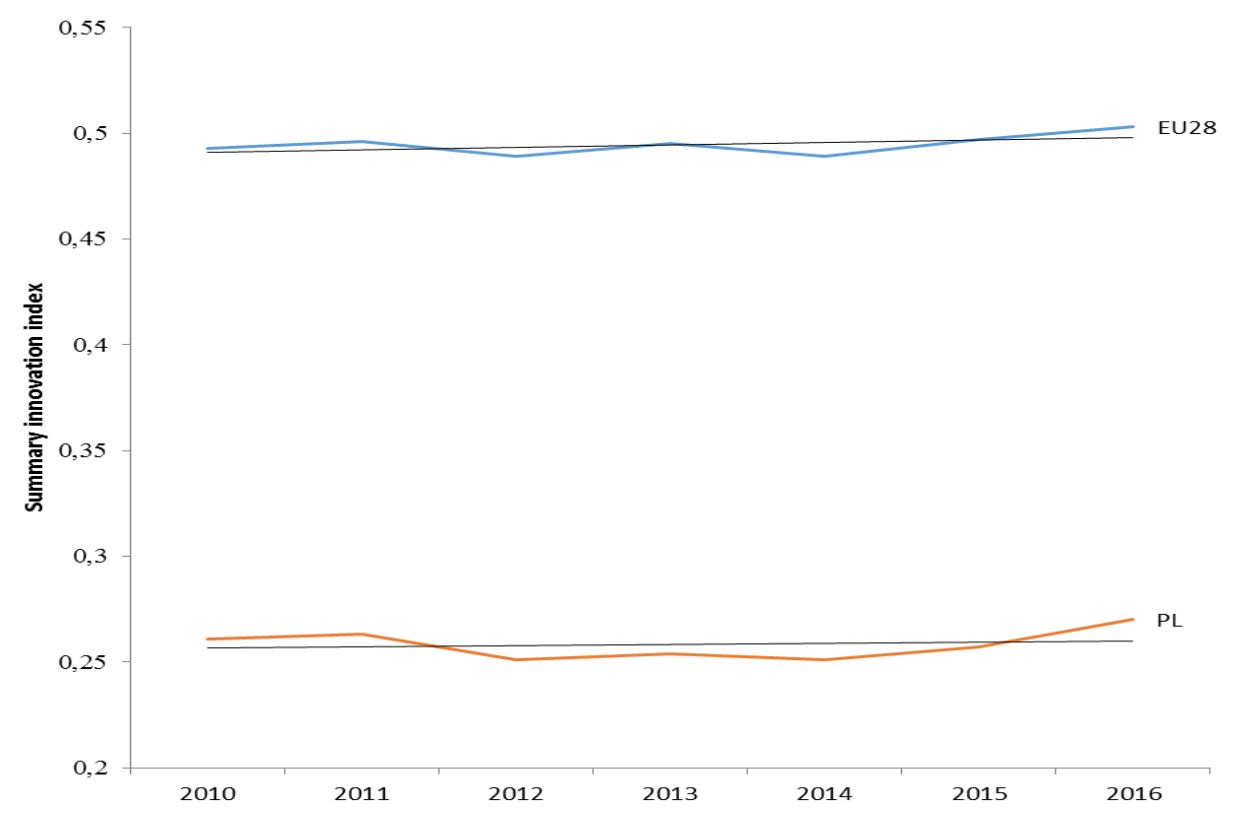

Figure 2. Summary innovation index in Poland compared to the EU average

Source: own elaboration based on European Innovation Scoreboard 2017.

Data analysis also indicates that in the case of the most innovative states, the private sector dominates in investments in R\&D activities. In the case of Denmark in the analysed period it was on average nearly 29 times greater than in the case of the public sector, and in Sweden nearly 17 times greater, in Finland nearly 8 times greater. Participation of the private sector was slightly lower in Germany, where its expenses were more than 4 times greater than in the public sector. One exception is Luxembourg, which shows lowering of the share of the private sector from 3.1 in 2010 to 1.6 in 2015, compared with the public sector. On average, this gave a factor of 2.2, the same as in the case of Bulgaria where the opposite trend can be observed. In other countries occupying the lowest positions of the innovativeness ranking, private sector expenditures compared to the public sector were between 0.9 in Romania to 1.8 in Croatia. The ratio of expenditures in the private sector to the public sector has been included in Table 1 .

The results seem to confirm that the European Union funds, which significantly supply the Polish economy, do not always provide sufficient source allowing for efficient stimulation of innovativeness. Therefore, it would be wise to seek for new solutions, particularly to develop incentives that would raise the share of expenditures of enterprises in terms of funding of $\mathrm{R}+\mathrm{D}$ activities.

Compilation of GDP of analysed states also shows that the top performers of the innovativeness ranking are characterised by a high level of GDP per capita. This in turn allows to spend larger amounts on innovative activities. In turn, states, whose innovativeness is low, are characterised by a significant growth of GDP. 
Table 1. The ratio of expenditures in the private sector to the public sector

\begin{tabular}{|l|c|c|c|c|c|c|}
\hline Country & 2010 & 2011 & 2012 & 2013 & 2014 & 2015 \\
\hline European Union (28 countries) & 4,8 & 5,1 & 5,2 & 5,2 & 5,3 & 5,3 \\
\hline Belgium & 8,0 & 8,5 & 8,7 & 8,7 & 8,7 & 9,3 \\
\hline Bulgaria & 1,4 & 1,5 & 2,0 & 2,1 & 2,7 & 3,5 \\
\hline Czech Republic & 2,7 & 2,8 & 2,9 & 3,0 & 3,1 & 2,7 \\
\hline Denmark & 30,4 & 32,9 & 27,6 & 26,9 & 27,4 & 27,4 \\
\hline Germany & 4,5 & 4,7 & 4,7 & 4,5 & 4,5 & 4,5 \\
\hline Estonia & 4,8 & 7,8 & 6,2 & 5,3 & 4,0 & 4,3 \\
\hline Ireland & 14,4 & 14,1 & 14,9 & 15,7 & 16,2 & 0,0 \\
\hline Greece & 1,7 & 1,5 & 1,4 & 1,2 & 1,2 & 1,2 \\
\hline Spain & 2,6 & 2,7 & 2,8 & 2,8 & 2,8 & 2,7 \\
\hline France & 4,5 & 4,6 & 4,9 & 5,0 & 5,1 & 5,0 \\
\hline Croatia & 1,6 & 1,6 & 1,7 & 2,0 & 1,8 & 2,1 \\
\hline Italy & 3,9 & 4,1 & 3,7 & 3,9 & 4,2 & 4,2 \\
\hline Cyprus & 0,9 & 0,9 & 0,9 & 1,1 & 1,2 & 1,2 \\
\hline Latvia & 1,6 & 1,2 & 0,8 & 1,0 & 1,5 & 1,0 \\
\hline Lithuania & 1,7 & 1,3 & 1,4 & 1,3 & 1,8 & 1,6 \\
\hline Luxembourg & 3,1 & 2,8 & 2,0 & 1,8 & 1,8 & 1,6 \\
\hline Hungary & 3,2 & 4,0 & 4,5 & 4,7 & 5,2 & 5,5 \\
\hline Malta & 14,1 & 15,0 & 7,2 & 5,4 & 5,5 & 2,8 \\
\hline Netherlands & 4,1 & 5,2 & 4,8 & 4,6 & 4,7 & 4,5 \\
\hline Austria & 13,1 & 13,4 & 15,4 & 15,9 & 16,0 & 15,9 \\
\hline Poland & 0,7 & 0,9 & 1,3 & 1,6 & 1,9 & 1,9 \\
\hline Portugal & 6,4 & 6,4 & 9,3 & 7,3 & 7,4 & 8,0 \\
\hline Romania & 1,0 & 0,9 & 1,0 & 0,6 & 1,0 & 1,1 \\
\hline Slovenia & 3,7 & 5,2 & 5,8 & 5,9 & 6,4 & 5,6 \\
\hline Slovakia & 1,4 & 1,3 & 1,7 & 2,3 & 1,3 & 1,0 \\
\hline Finland & 7,5 & 8,0 & 7,6 & 7,7 & 7,8 & 8,2 \\
\hline Sweden & 14,1 & 16,0 & 14,1 & 18,7 & 17,9 & 20,2 \\
\hline United Kingdom & 6,4 & 7,4 & 7,9 & 8,1 & 9,0 & 9,7 \\
\hline Source & & & & & \\
\hline
\end{tabular}

Source: own elaboration based on Eurostat data.

Figure 3, which presents the dynamics of GDP and the level of innovativeness, allows to observe a certain regularity. It says that the most innovative states (Sweden, Finland, Denmark, Germany) are characterised by low GDP growth. On the other hand, those with low innovativeness (Bulgaria, Poland, Romania, Malta, Slovakia) can demonstrate the significant growth. This is confirmed by the fact that the development of economies of the so-called catching-up states is primarily the result of implementing solutions transferred from more developed countries. In addition, development is based on the low labour cost that characterises these countries. Labour cost of innovation leaders is among the highest in the European Union, which inhibits the dynamics of GDP. Nevertheless, high level of innovativeness allows to keep it on a positive level. 


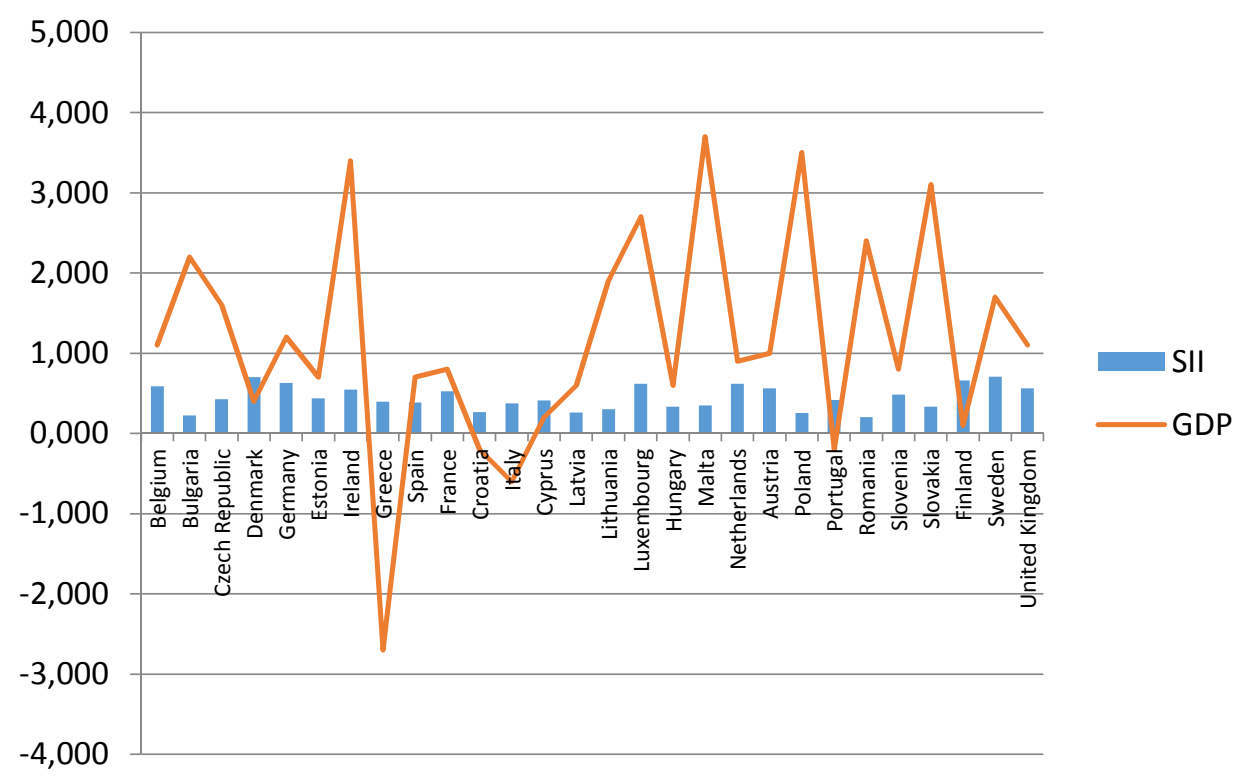

Figure 3. GDP growth and summary innovation index

Source: own elaboration based on Eurostat data and European Innovation Scoreboard 2017.

\section{CONCLUSIONS}

Analysis of the available data regarding the financing of $R \& D$ activities indicates the low interest of private enterprises in countries that occupy low positions in terms of innovativeness in the European Union. It may also be the result of smaller readiness of domestic market to accept innovation. In the case of the leaders, share of the private sector is dominant in financing of pro-innovation activities. Based on the results obtained, we can formulate a thesis that public spending is less efficient and effective than in the case of private funds. In addition, there is concern that these measures could destabilise the market and impair competition. Polish example shows that EU funds do not guarantee the appropriate pace of development allowing to achieve a trend that would guarantee getting good results in the long term and reduce the gap.

Summary of GDP dynamics and innovative position of individual countries indicates that in this case there is an inverse relationship. After considering the additional labour costs, it can be said that poor innovativeness forces us to seek opportunities to develop economy based on low costs and development of production orientation. It may be a good solution in the initial period of catching-up, but in the case of the European Union it is difficult to clearly observe the occurrence of the phenomenon of convergence, because the position and distance of individual states are rather stable.

The observed regularities seem to clearly indicate the need to search for new instruments to increase innovativeness, which is confirmed by the Polish case, who, despite a significant 
share in the redistribution of EU funds, has not been able to achieve an appropriate pace of development yet. If innovations, especially ground-breaking ones, are to be the driving force of the economy, and these in turn require incurring the expenditure on R\&D activities, it is necessary above all to stimulate the private sector to get it involved in its financing. For this purpose, it is not enough to use only the financial instruments in the form of grants. It may also be important to reconstruct the state's micro-economic policy through the introduction of other pro-innovative solutions.

In relation to public expenditures, it may be wise to additionally bonus innovative enterprises, especially, especially those acting on an international scale. Public expenditures are important in creating development, however, we must remember that they are complementary to private expenditures and cannot replace them. Additionally, we must secure rational spending. Non-refundable grants are recommended in areas where there is significant risk. Where the risk is lower, and only imperfections of financial markets limit investments, we should consider the use of refundable instruments (even taking into account preferential conditions for innovators).

Additional results from the analysis of the available data indicate that the low interest of the private sector in innovation financing may be due to the fact that the market does not need them. Perhaps the right conditions for the development of innovation will be available by achieving the optimum level of GDP per capita, as higher incomes associated with it could stimulate demand for innovation. Yet, it is important to constantly employ innovation policy so that the economy is not stuck in the middle income trap.

\section{REFERENCES}

1. Bukowski M, Szprot A., Śniegocki A., Innowacyjność polskiej gospodarki, „Ekonomia i Zarządzanie" 2014, nr 1.

2. Cameron G., Innovation and Economic Growth, CEP Discussion Papers No. 277, Centre for Economic Performance, London School of Economics and Political Science, London 1996.

3. Drucker P.F., Innowacja i przedsiębiorczość. Praktyka i zasady, PWE, Warszawa 1992.

4. Fagerberg J., Technology Gap Approach to Why Growth Paths Differ, „Research Policy“ 1987, Vol. 16.

5. Frankowski P., Skubiak B., Innowacyjność w teorii ekonomii i praktyce gospodarczej, Studia i Prace Wydziału Nauk Ekonomicznych i Zarządzania 2012, nr 30.

6. Freeman C., Soete L., The Economics of Industrial Innovation. 3rd Edition, Routledge, London 1997.

7. Janasz W., Kozioł K., Determinanty działalności innowacyjnej przedsiębiorstw, PWE, Warszawa 2007.

8. Khan M., Luintel K.B., Sources of Knowledge and Productivity: How Robust is the Relationship?, OECD Science, Technology and Industry Working Papers 2006, nr 6, OECD, Paris 2006.

9. Kowalik J., Analiza poziomu innowacyjności państw Unii Europejskiej, Zeszyty Naukowe Politechniki Częstochowskiej Zarządzanie 2015, nr 19.

10. Matusiak K.B. (ed.), Innowacje i transfer technologii. Stownik pojęć, Polska Agencja Rozwoju Regionalnego, Warszawa 2011. 
11. Nawrocki T., Innowacyjność produktowa przedsiębiorstw, CeDeWu, Warszawa 2012.

12. OECD, Oslo Manual. Guidelines for Collecting and Interpreting Innovation Data, 3rd Edition, The Organisation for Economic Co-operation and Development, 2005.

13. Okoń-Horodyńska E., Rola polskiej nauki we wzroście innowacyjności gospodarki, PTE, Warszawa 2004.

14. Pece A.M., Simonab O.E., Salisteanuc F., Innovation and economic growth: An empirical analysis for CEE countries. „Procedia Economics and Finance” 2015, No. 26.

15. Pomykalski A., Zarzadzanie innowacjami, PWE, Warszawa-Łódź 2001.

16. Porter M.E., The Competitive Advantage of Nations, The Macmillan Press Ltd, London 1990.

17. Schumpeter J.A., Business Cycles: A Theoretical, Historical and Statistical Analysis of the Capitalist Process, Porcupine Press, Philadelphia 1982.

18. Simpson P.M., Siguaw J.A., Enz C.A., Innovation orientation outcomes: the good and the bad, ,Journal of Business Research“ 2006, Vol. 59, Issue 10.

19. Ulku H. R\&D, Innovation, and Economic Growth: An Empirical Analysis, „IMF Working Paper" 2004, No. 185.

20. Weresa M., Polityka innowacyjna, PWN, Warszawa 2014.

21. Wyrwa D., Evaluation of the efficiency of the European Union's innovative policy, „Actual Problems of Economics" 2017, No. 1.

22. Zalewski A., Reformy sektora publicznego $w$ duchu nowego zarzadzania publicznego [in:] Nowe zarzadzanie publiczne w polskim samorzadzie terytorialnym, ed. A. Zalewski, SGH, Warszawa 2007.

\section{DYLEMATY TWORZENIA POLITYKI INNOWACJI W PAŃSTWACH CZŁONKOWSKICH}

Kierunki zmian zachodzących w gospodarce światowej w ostatnich latach wskazują na przekształcenie gospodarki przemysłowej w gospodarkę opartą na wiedzy, wykorzystującą potencjał technologiczny i innowacyjny. Taka transformacja uwidoczniła przewagi konkurencyjne krajów i regionów specjalizujących się w produkcji zaawansowanych produktów. Celem artykułu jest zbadanie wpływu wydatków na badania i rozwój $(B+R)$ na wzrost gospodarczy w państwach członkowskich Unii Europejskiej. Ponadto podjęta została próba dokonania oceny, czy istnieje znaczący związek między poziomem nakładów na tę działalność w poszczególnych krajów i ich innowacjami oraz między innowacjami a dochodem na mieszkańca, jak to jest postulowane przez endogeniczne modele wzrostu oparte na badaniach i rozwoju. Podstawowym źródłem informacji wykorzystanych do przeprowadzonej analizy była baza danych Eurostatu oraz raporty European Innovation Scoreboard. Otrzymane wyniki potwierdzają dodatni i statystycznie istotny wpływ rządowych wydatków na badania i rozwój, który jest główną siłą napędową wzrostu gospodarczego w analizowanym okresie. Kraje wysoko rozwinięte prowadzą badania mające na celu poszukiwania nowych źródeł innowacyjności i metod tworzenia potencjału innowacyjnego. Nakłady na innowacyjność często przynoszą długofalowe korzyści poprzez możliwość uzyskania pozycji lidera przez te kraje. Uzyskane wyniki pozwalają również stwierdzić, że kraje Unii Europejskiej, które nie mają 
efektywnych sektorów badawczo-rozwojowych, wydają się promować swoje innowacje poprzez transfer technologii z innych państw. Takie postępowanie nie pozwoli im na zaatakowanie pozycji liderów. Mogą wykorzystywać jedynie strategię naśladownictwa.

Słowa kluczowe: innowacje, polityka innowacyjna, wzrost gospodarczy.

DOI: $10.7862 /$ rz.2018.mmr.18

Tekst ztożono w redakcji: marzec $2018 \mathrm{r}$.

Przyjęto do druku: czerwiec 2018 r. 